\title{
THE EVALUATION OF THE THERMO-HYGROMETRIC PARTICULARITIES OF SUCEAVA MUNICIPALITY (ROMANIA) FROM TOPOCLIMATIC PERSPECTIVE
}

DOI: http://dx.doi.org/10.18509/GBP.2020.21

UDC: 551.588.7:551.57(498)

\author{
Alin Prisacariu ${ }^{1}$ \\ Dumitru Mihăilă ${ }^{1}$ \\ Petruț Ionel-Bistricean ${ }^{2}$ \\ ${ }^{1}$ Department of Geography, Faculty of History and Geography, \\ Stefan cel Mare University, Suceava, Romania \\ ${ }^{2}$ Regional Meteorological Centre of Moldova, \\ National Meteorological Administration, Suceava, Romania
}

\begin{abstract}
The topoclimate of a city in full development and territorial expansion such as Suceava Municipality (Romania) must be known and properly appreciated through the view of the basic meteorological elements values.

The study aims to identify the progressive and distributional particularities of the air temperature and atmospheric humidity, based on the data provided by a network of 24 thermo-hygrometric sensors. In order to be able to capture the local thermal and hygrometric differences as much as possible, we will compare the distribution of the air temperature and humidity values for two characteristic periods of the observation interval: the 2018 - 2019 astronomical winter, respectively the 2019 astronomical summer. For the two seasons, the analyses will be performed separately for day and night hours.

The main objectives of the study are:

- identification of the hottest / coldest and respectively driest / most humid areas from the urban atmosphere,

- the causal scientific reasoning of their thermal and hygric character,

- identification of the aspects of influence of the thermo-hygrometric complex on the components of the geographical environment,

- evaluation of the temperature and atmospheric humidity importance in the outlining of the topoclimates of Suceava municipality.
\end{abstract}

Keywords: thermo-hygrometric sensors, urban atmosphere, topoclimates

\section{INTRODUCTION}

Climate research in metropolitan areas, was for a log period, a descriptive method meant to present meteorological phenomenon and processes, based on classic measurements from meteorological stations. Nowadays, those measurements explains the topoclimatic differentiations occurred between the urban and suburban areas or just inside the urban areas.

Urban climatology have suffered an evolution, from vague mentions in some urban monographs, till microclimatic researches. The new measuring devices for the physical state of the urban atmosphere, the possibility to register and automatic store of the 
measurements, were meant to point out the changes which may appear inside the urban topoclimate and microclimate areas, mostly determined by human impact.

The microclimate complex from Bucharest metropolitan area, was analysed by means of meteorological mobile stations in 2008 [1]. Furthermore, was analysed the urban heat island by using climatic profiles method. To highlight the influence of topoclimate in Iaşi city, in 2012, were used sensors for temperature and humidity measurements [2].

A methodology for delineation and quantification of urban heat island was exemplified for Bucharest, in 2015 [3]. The characteristics of nocturnal urban heat island of Iaşi during a summer heat wave, have been investigated in 2017 [4], the matter of physico-geographic factors on this phenomenon are essentials for the study. Another studies, excluding the territory of Romania, were implemented in order to analyse in detail, the urban microclimate and topoclimate in 2014 [5], 2016 [6], 2017 [7] or 2018 [8].

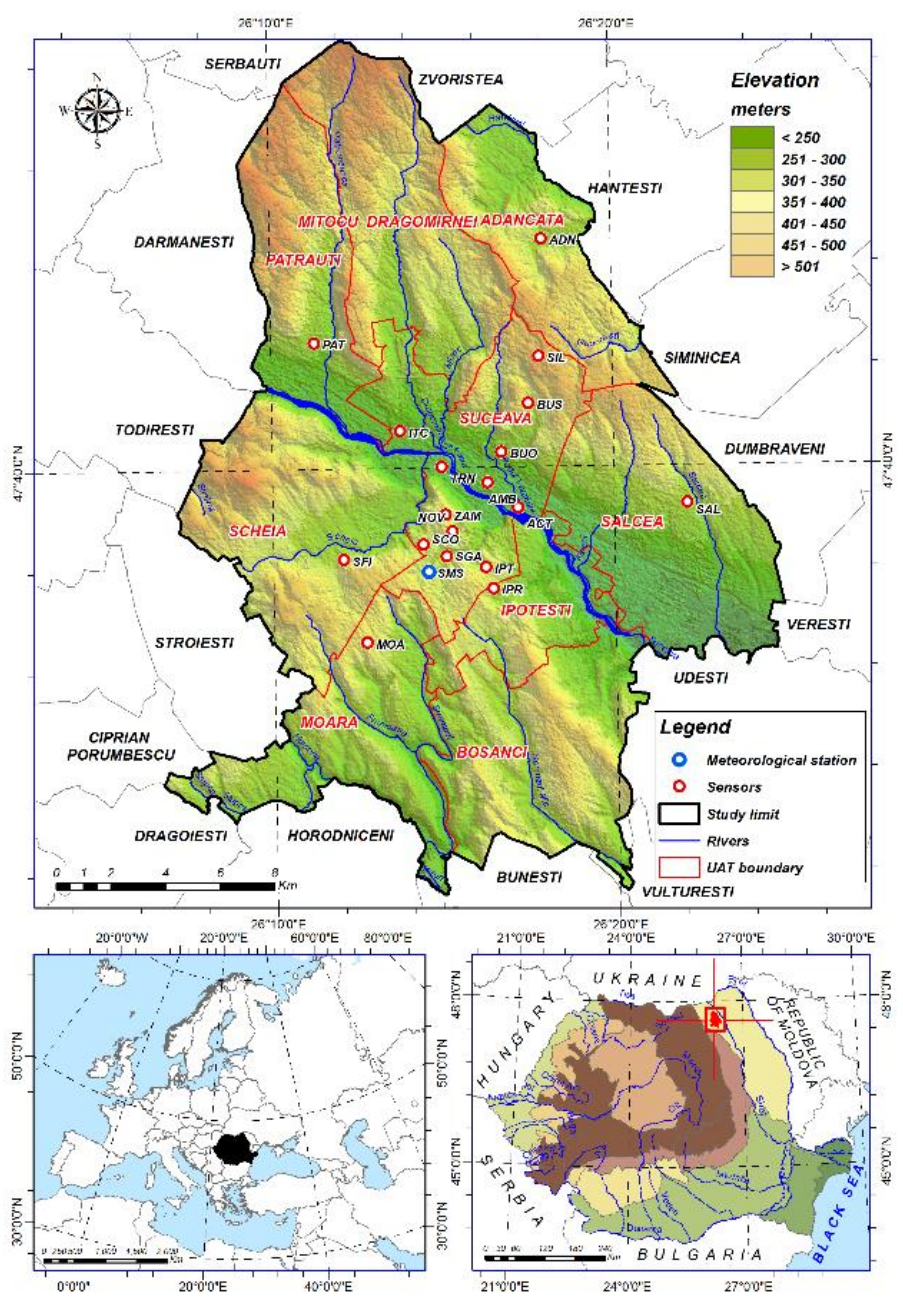

Figure 1. Territorial repartition of meteorological monitoring points from metropolitan area of Suceava (above), localisation of Suceava City in Romania (right part), and localisation of Romania in Europe (left part)

The study area includes Suceava Municipality and the rural surroundings, totalling an area of $406,88 \mathrm{~km}^{2}$ (Fig. 1).

Suceava City is one of the oldest and important urban area from Romania, being first mentioned in 1388. Suceava was the capital of the Principality of Moldavia during two centuries. 
The study area presents a specific type of relief, the hilly area being fragmented by river valleys, determining cuestas and structural plateaus as principal landform.

The Suceava City is crossed by Suceava River from NV to SE. It has also some tributary rivers influencing the air circulation and determines the main characteristics for the microclimate and the topoclimate in the studied region.

\section{Materials}

The data used for this study come from a specialised network with 18 termo-hygrometric sensors, and from the Meteorological Suceava Station. The position of the sensors took in consideration the surface cover of the Suceava Municipality and also the particularities of those elements according to different types of active surface (Tab. 1).

Table 1. Meteorological monitoring points

\begin{tabular}{|c|c|c|c|c|c|}
\hline $\begin{array}{l}\mathrm{Nr} . \\
\text { post }\end{array}$ & Name & Indicative & Latitude & Longitude & $\begin{array}{l}\text { Altitude } \\
\text { (m) }\end{array}$ \\
\hline 1 & Adâncata & AND & $47^{\circ} 44^{\prime} 30.593^{\prime \prime} \mathrm{N}$ & $26^{\circ} 17^{\prime} 57.936^{\prime \prime} \mathrm{E}$ & 347 \\
\hline 2 & Pătrăuţi & PAT & $47^{\circ} 42^{\prime 29} .964^{\prime \prime} \mathrm{N}$ & $26^{\circ} 11^{\prime} 16.310^{\prime \prime} \mathrm{E}$ & 312 \\
\hline 3 & Ocolul Silvic Adâncata & SIL & $47^{\circ} 42^{\prime} 11.116^{\prime \prime} \mathrm{N}$ & $26^{\circ} 17 ' 50.521^{\prime \prime} \mathrm{E}$ & 440 \\
\hline 4 & Burdujeni - sat & BUS & $47^{\circ} 41^{\prime} 15.346^{\prime \prime} \mathrm{N}$ & $26^{\circ} 17^{\prime} 31.034^{\prime \prime} \mathrm{E}$ & 366 \\
\hline 5 & Ițcani & ITC & $47^{\circ} 40^{\prime} 44.374^{\prime \prime} \mathrm{N}$ & $26^{\circ} 13^{\prime} 45.614^{\prime \prime} \mathrm{E}$ & 279 \\
\hline 6 & Burdujeni - oraş & BUO & $47^{\circ} 40^{\prime} 17.842^{\prime \prime} \mathrm{N}$ & $26^{\circ} 16^{\prime} 42.660^{\prime \prime} \mathrm{E}$ & 306 \\
\hline 7 & Turn & TRN & $47^{\circ} 40^{\prime} 1.093^{\prime \prime} \mathrm{N}$ & $26^{\circ} 14^{\prime} 57.145^{\prime \prime} \mathrm{E}$ & 274 \\
\hline 8 & Ambro & AMB & $47^{\circ} 39^{\prime} 41.895^{\prime \prime} \mathrm{N}$ & $26^{\circ} 16^{\prime} 17.619^{\prime \prime} \mathrm{E}$ & 289 \\
\hline 9 & Zamca & ZAM & $47^{\circ} 39^{\prime} 4.512^{\prime \prime} \mathrm{N}$ & $26^{\circ} 15^{\prime} 2.978^{\prime \prime} \mathrm{E}$ & 368 \\
\hline 10 & Salcea & SAL & $47^{\circ} 39^{\prime} 15.140^{\prime \prime} \mathrm{N}$ & $26^{\circ} 22^{\prime} 8.038^{\prime \prime} \mathrm{E}$ & 338 \\
\hline 11 & ACET & ACT & $47^{\circ} 39^{\prime} 11.662^{\prime \prime} \mathrm{N}$ & $26^{\circ} 17^{\prime} 10.538^{\prime \prime} \mathrm{E}$ & 270 \\
\hline 12 & 6 Noiembrie & NOV & $47^{\circ} 38^{\prime} 44.595^{\prime \prime} \mathrm{N}$ & $26^{\circ} 15^{\prime} 14.804^{\prime \prime} \mathrm{E}$ & 363 \\
\hline 13 & Şcoala nr. 4 & SCO & $47^{\circ} 38^{\prime} 29.155^{\prime \prime} \mathrm{N}$ & $26^{\circ} 14^{\prime} 23.413^{\prime \prime} \mathrm{E}$ & 360 \\
\hline 14 & SGA garaj & SGA & $47^{\circ} 38^{\prime} 14.871^{\prime \prime} \mathrm{N}$ & $26^{\circ} 15^{\prime} 3.871^{\prime \prime} \mathrm{E}$ & 333 \\
\hline 15 & Sfântul Ilie & SFI & $47^{\circ} 38^{\prime} 12.501^{\prime \prime} \mathrm{N}$ & $26^{\circ} 12^{\prime} 3.706^{\prime \prime} \mathrm{E}$ & 356 \\
\hline 16 & Ipoteşti 1 & IPT & $47^{\circ} 38^{\prime} 1.447^{\prime \prime} \mathrm{N}$ & $26^{\circ} 16^{\prime} 13.026^{\prime \prime} \mathrm{E}$ & 358 \\
\hline 17 & Staţia Meteorologică & SMS & $47^{\circ} 37^{\prime} 57.087^{\prime \prime} \mathrm{N}$ & $26^{\circ} 14^{\prime} 32.243^{\prime \prime} \mathrm{E}$ & 360 \\
\hline 18 & Ipoteşti Radu & IPR & $47^{\circ} 37^{\prime} 36.189^{\prime \prime} \mathrm{N}$ & $26^{\circ} 16^{\prime} 25.490^{\prime \prime} \mathrm{E}$ & 364 \\
\hline 19 & Moara & MOA & $47^{\circ} 36 ' 33.764^{\prime \prime} \mathrm{N}$ & $26^{\circ} 12^{\prime} 42.778^{\prime \prime} \mathrm{E}$ & 387 \\
\hline
\end{tabular}

For the meteorological monitoring of the Suceava metropolitan area, was used a thermohygrometer sensor type DATA LOGGER DT - 171 (Fig. 2).

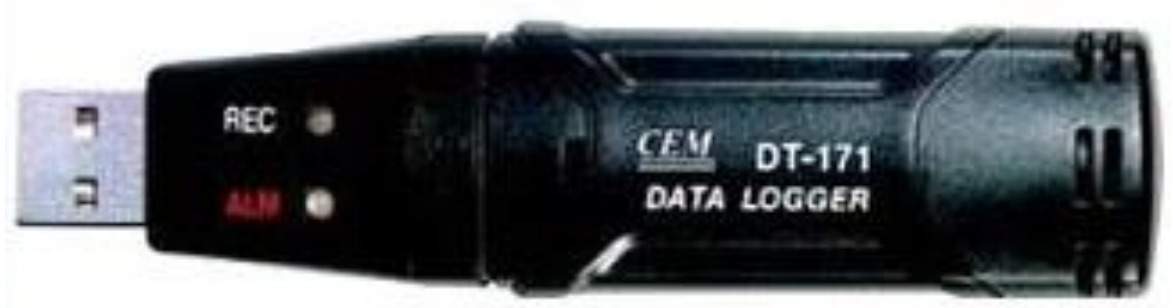

Figure 2. Thermo-hygrometer Data Logger DT - 171

The 18 sensors were positioned in meteorological shelters, made by wood, with a specific structure which offers a good circulation of the air, but at the same time, preventing the direct contact of the sensors with the solar radiation. The shelters with dimensions of $400 / 400 / 400 \mathrm{~mm}$, with ventilation, thermo-isolated and waterproof roof are positioned on wood pillars, at $2 \mathrm{~m}$ high (Fig. $3 \mathrm{a}$ and b). 
The sensors have the capacity to register 32000 data, of which 16000 are for temperature and humidity. The registered temperature is in the range $-40^{\circ} \mathrm{C}$ and $+70^{\circ} \mathrm{C}$, with the accuracy of $1,0^{\circ} \mathrm{C}$ for the temperatures ranging from $-10^{\circ} \mathrm{C}$ and $+40^{\circ} \mathrm{C}$, and of $\pm 2^{\circ} \mathrm{C}$ for the others thermic intervals.
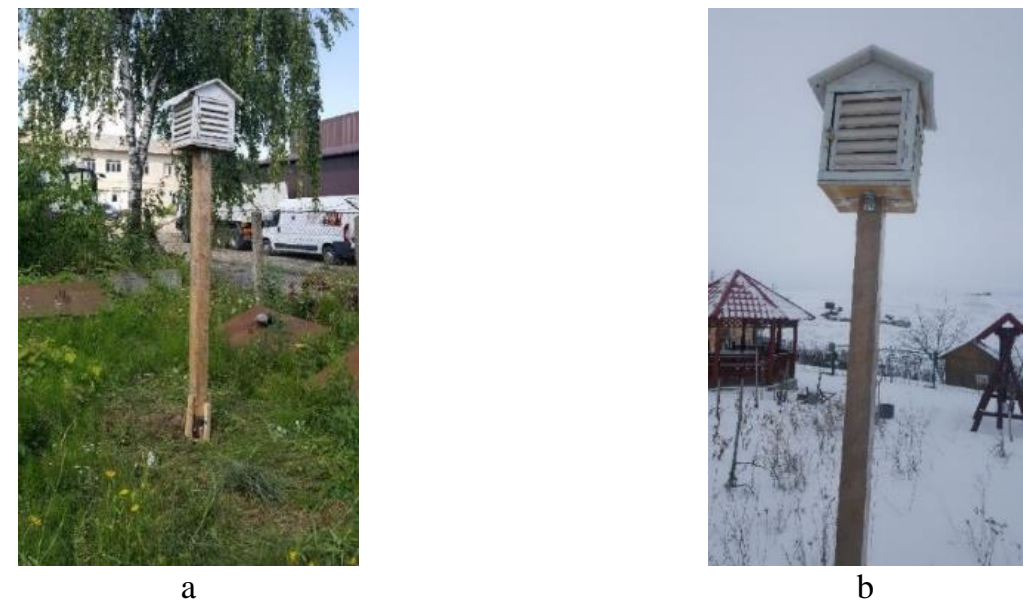

Figure 3. Meteorological shelters at SGA Suceava - SGA (a) and Ipoteşti - IPT

The relative humidity is in the range $0-100 \%$, with the accuracy between $\pm 3.0- \pm 5.0$ $\%$. All the data collected were transferred to a PC, using a USB cable. The viewing software was automated installed, the data being exported in .txt and/or .xls format. Were also used some data registered at the Meteorological Station from Suceava.

\section{Methods}

The sensors were set to register the temperature and humidity, hour by hour, according with the time of registration of the Meteorological Station of Suceava. The data obtained have been statistically processed, obtaining plots and maps in order to assess the results, and to build future scenarios, meant to predict the state of the climate.

The modality of data processing involved also some errors determined by the differences between the field measurements and the results obtained according with data processing and cartographic results. The differences between the mean of the values registered in the field and those represented by the cartographic model, were in the area of the 19 points of observation, ranging from 0,00 and $0,01^{\circ} \mathrm{C}$, for the 8 th sets of temperature maps, and ranging between 0,00 and $0,01 \%$ for the 8 th relative humidity maps.

The value deviations from the maps, compared with the field measurements are in the case of temperature between $+0,10$ and $-0,11^{\circ} \mathrm{C}$, and between $+0,15$ and $-0,11 \%$ in the case of relative humidity. According this, the maps obtained are of good accuracy.

For data interpolation in order to obtain the maps, we have used o hybrid method from the multiple regression and a deterministic mathematic method (IDW - Inverse Distance Weighting) [9], combining a global model of interpolation (multiple regression) with a local one which use values from the vicinity of the interpolation point (IDW).

In the first stage it is determined the spatial tendency of the analysed value by applying the multiple regression, in the second step, the spatial tendency is extracted from the baseline. The differences between the real values and the estimated ones by the regression, were interpolated using the IDW method. After that, the raster with the surpluses date interpolated was added to the spatial tendency, resulting the spatial representation of the analysed variable (temperature or humidity). 


\section{Data obtained}

The sensors were set to register the temperature and the humidity hour by hour, in the same time with the data registration from the Meteorological Station of Suceava. The period that have been taken into account are:

- For the winter period we have used data starting from 20 December 2018 and 20 March 2019. The analysis was made during day (8AM - 5PM) and night (6PM 7AM).

- For the summer period we have used data starting from 21 July 2019 and 23 September 2019. The analysis was made during day (6 AM - 8PM) and night (9PM $-5 \mathrm{AM})$.

\section{RESULTS AND DISCUTIONS}

The value of the differences of temperature and relative humidity of the air in the Metropolitan area of Suceava (AMSV), were measured in 18 work points and were reported at the same parameters calculated Meteorological station of Suceava (SMSv). Those differences are the main cause of the specificity of active surface, which is characterized by heterogeneity.

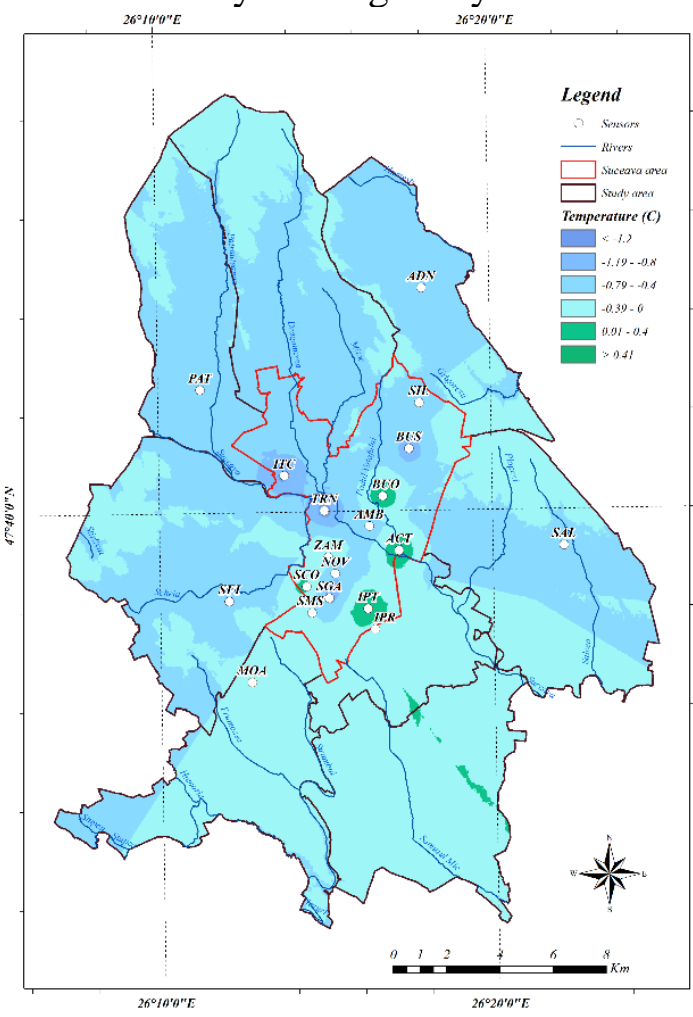

Figure 4. Territorial repartition of the air during winter nights for the range $18^{00}-07^{00}$

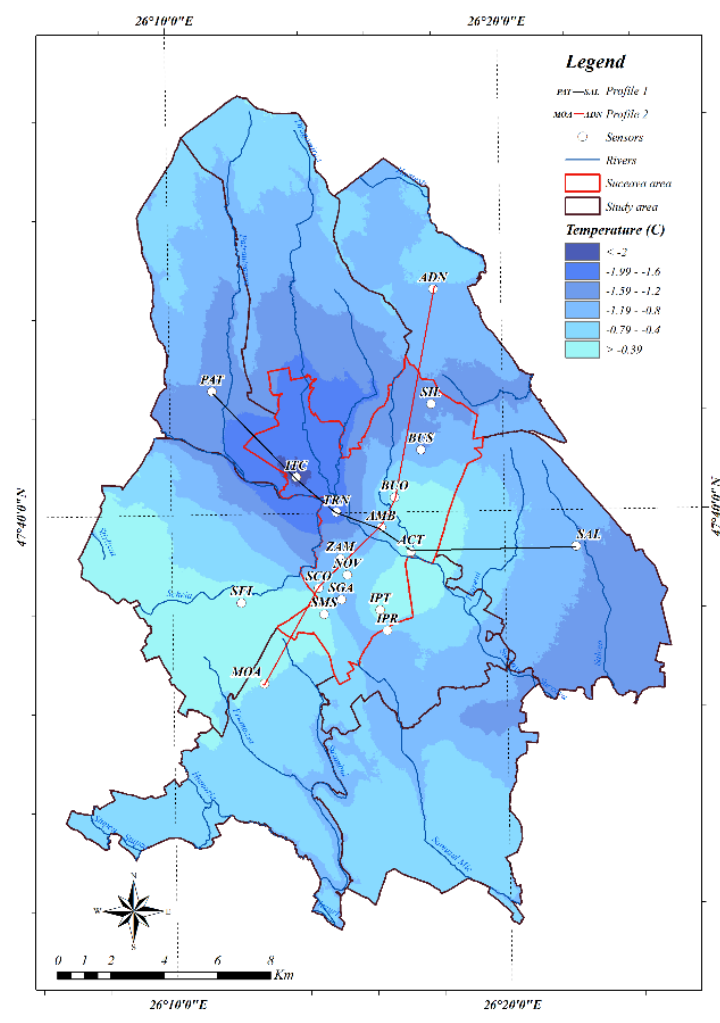

Figure 5. Territorial repartition of the air during winter nights for the range $01^{00}-04^{00}$

The territorial differences of reflectance, absorption, solar radiation emission, the heat generated by anthropogenic sources, the infiltration processes, evaporation, evapotranspiration have been affected. Because of this heterogeneity, the local dynamic of air was diminished in some areas, favouring the air stability and stagnation, or in opposite, in some areas, it was streamlined, favouring air turbulences. Also, the differences regarding the relief, the typology and active surface dynamic, have delineated 
some thermo-dynamic characteristics with higher or lower values reported to the value calculated at $2 \mathrm{~m}$ high, at Meteorological station of Suceava (SMSv).

During winter nights (6PM - 7AM - Fig.4) or in the range 1AM and $4 A M-$ Fig. 5, in distribution of the air temperature, we have some factors which determines the thermic differences.

The climatic factors contribute to the atmospheric dynamic or atmospheric stability by the influence which they exert by moving air from high areas to the lowest ones (floodplains, depressions)

The anthropogenic and the natural factors have influenced the repartition of the temperature. During winter nights we can observe that after middle night till morning, two areas with thermic differences, one with high temperatures and one with lowest thermic values.

The area with high temperature is divided in two: Burdujeni Neighbourhood with a high density of multi-stage buildings (meteorological station - PM BUO), continues by the East of the industrial platform to the warmer water basins of the Wastewater Treatment Plant, and the heating system of the city - ACET (PM ACT), till the build-up-area of Ipoteşti village. Ipoteşti village area is characterized by a favourable slope and aspect (PM IPT and IPR), fact which determines high temperature.

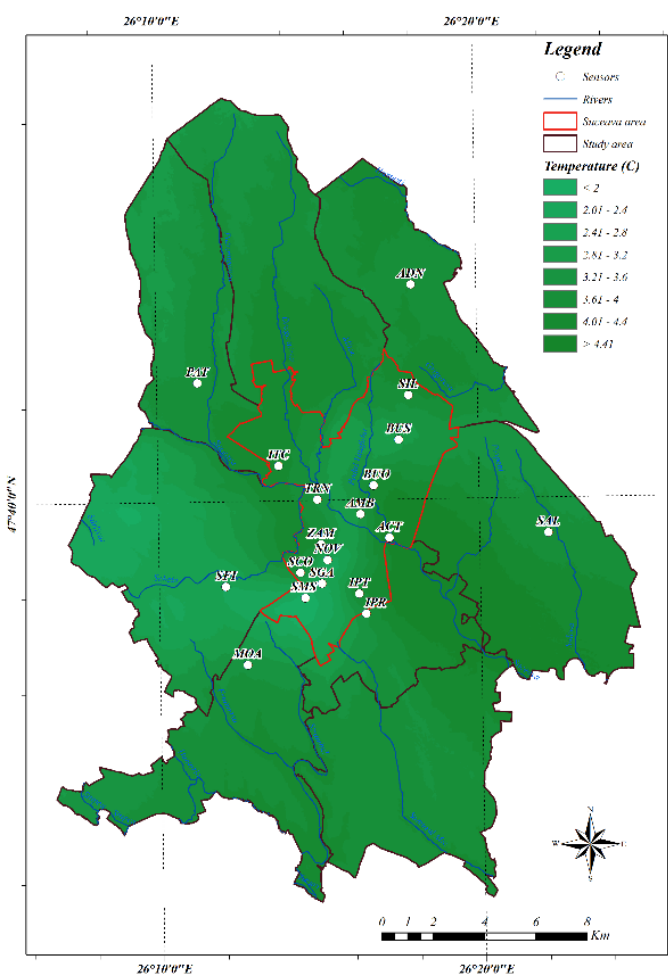

Figure 6. Repartition of air temperature during winter days for the range $08^{00}-17^{00}$

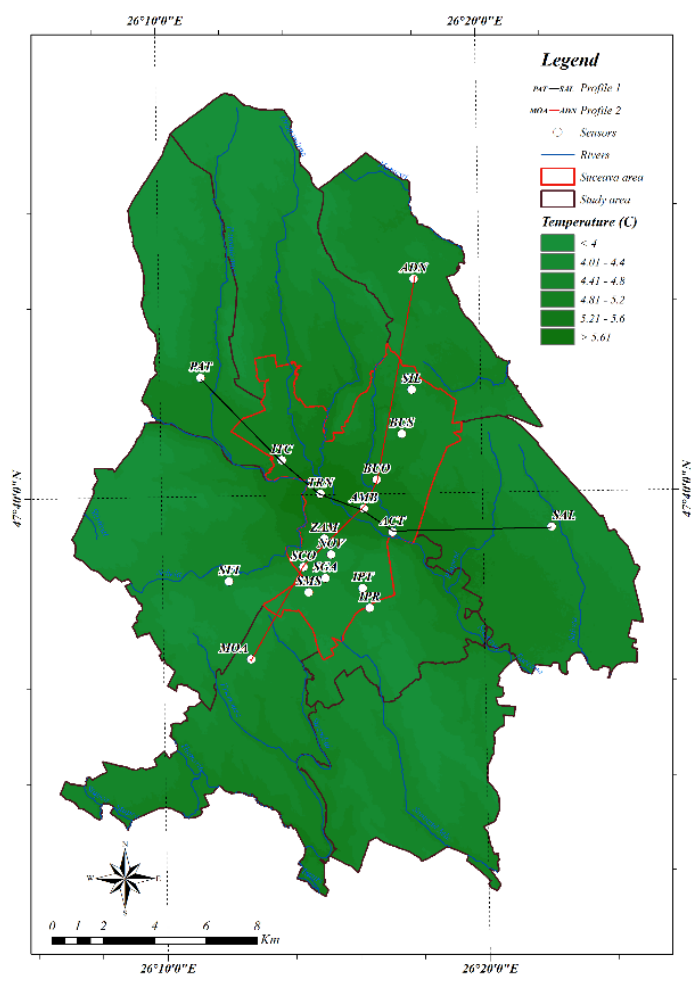

Figure7. Repartition of air temperature during winter days for the range $13^{00}-16^{00}$

The second area with high temperatures, where the anthropogenic influence represented by the density of the buildings and the socio-economic activity, is conditioned also by all the characteristics of the relief - steep slopes, reached some data from PM SFI, MOA and SCO.

The linkage between those two warmed areas is disrupted by a narrow and lowest area with low temperature, localized up to Cetăţii River (PM SGA). It continues toward the 
neighbourhood from Zamca Hill (the highest part of the city) - PM ZAM. The area becomes larger in the region of the embankment railway (Iţcani and Burdujeni rail station). This part acts like a "border" in case of air circulation - NV-SE direction.

On both sides of the embankment -PM TRN in SE, and ITC in NV with expansion towards PM PAT, are favoured the atmospheric condition of stability and reverse stratification of the air.

We have an area where thermic inversions are frequent, intense and longer and the main consequence is that the thermal minimum during the winter 2018 - 2019, was registered there $\left(-12,5^{\circ} \mathrm{C}\right.$, at PM TRN in the night of 7.01.2019).

As a conclusion, for winter nights, we can note that the anthropogenic factor is responsible for the appearance of a warmer place around PM BUO, ACT, IPT, IPR points in the central-eastern part of the city, surrounded by coldest areas.

The first place is situated in the central-western part of the city, around PM TRN, ITC and PAT, and his existence is related with the natural factor (floodplain region) and with the human impact by the other side (the embankment of the railway, which connects the Itcani and Burdujeni rail stations; and the obstacle represented by all the buildings from Burdujeni neighbourhood, both of those factors reducing the dynamic of air circulation, along Suceava River on NV-SE direction).

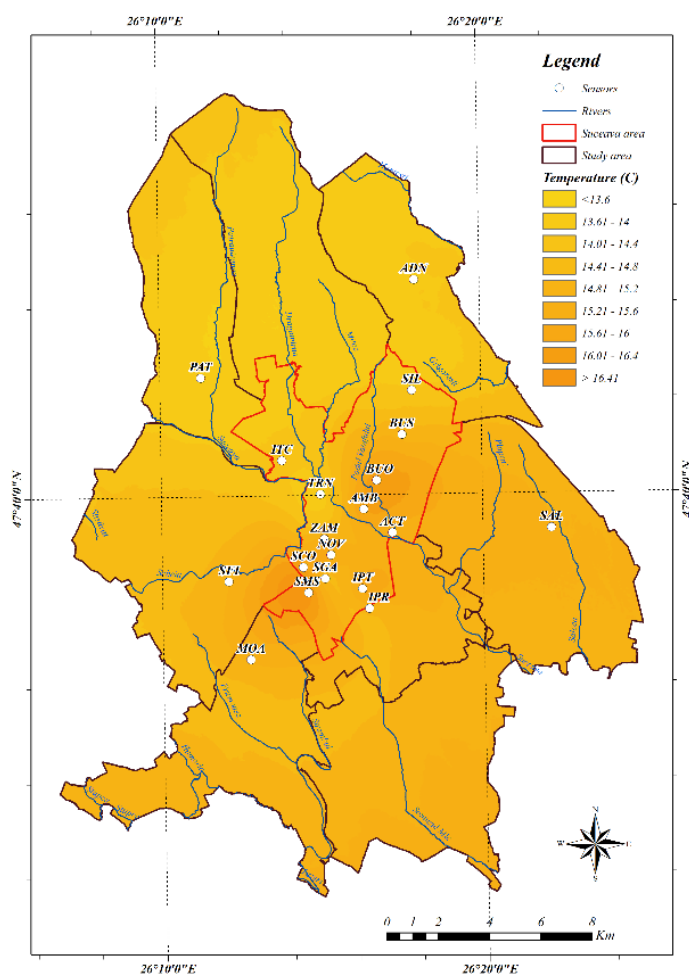

Figure 8. Repartition of air temperature during summer nights for the range $21^{00}-05^{00}$

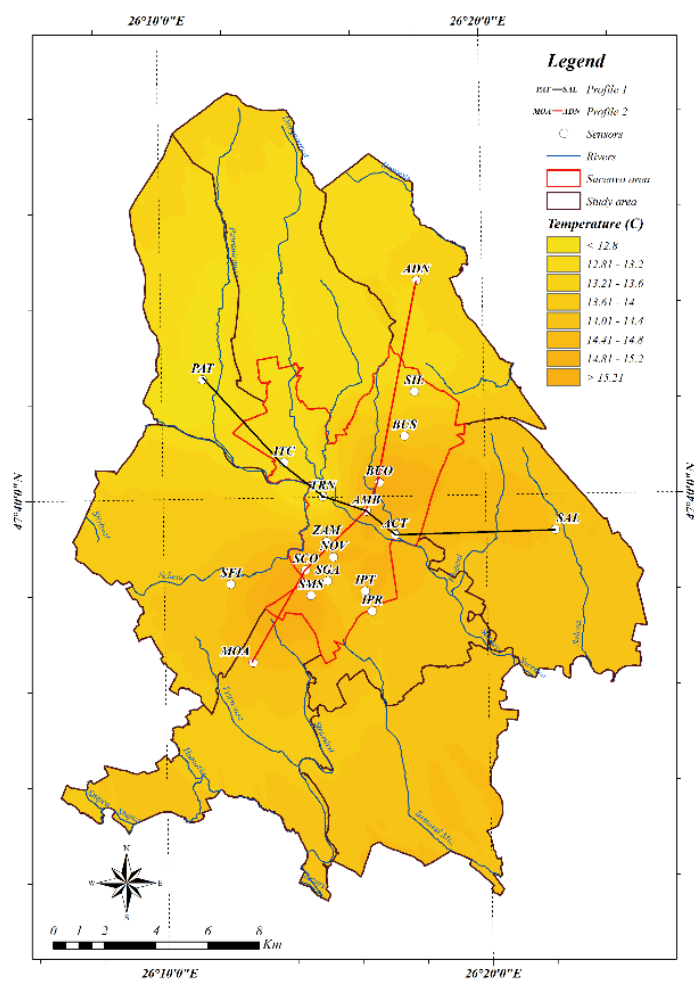

Figure 9. Repartition of air temperature during summer nights for the range $01^{00}-04^{00}$

The second one is situated in the South-Eastern extremity of the city, on the both sides of Suceava River Valley. It appears on the same time with the diminishing of the thermic anthropogenic influence around PM BUO, ACT, IPT, IPR. Suceava City has several urban cores, with an elongated form on the SV-NE direction (with another several expanses), is fragmented by the Suceava Valley, determining the topoclimate and the microclimate, due to tributary rivers. All the landforms type from the analysed region did not lead to the identification of the urban heat island 
in the southern part of the city. PM SCO indicates for the neighbourhoods from the southern part of Suceava, some thermic changes, which could be much better monitored by implementing more sensors or through satelitary infrared products.

Analysing the map of temperature distribution during winter days, could be observed 2 thermic cores. The first core is located in the central-eastern part of the city, at SE of PM BUO and ACT -territories where the temperature is conditioned by the human impact at the same proportion with the natural triggering factors (low regions with a better circulation of the air) - Fig. 6. The second core is located in the central-western part, at NV of PM SCO, ZAM, including PM TRN, ITC and PAT, influenced by the anthropogenic factors (the city - PM SCO) and in the same time, by the cumulated action of anthropogenic and natural factors (lowlands with near-horizontal exposure or with S-SE exposure - PM TRN, ITC, PAT, covered by build-up-area) - Fig. 7. There is also a coldest area along the stations: PM SFI, SMS, SGA, BUS, SAL, which are positioned at high altitude, in good conditions of air circulation, along or in the vicinity of som tributary rivers of Suceava River. Starting for this cause, the air temperature is low - Fig. 6. During middle day of winter time, we can observe around the PM BUO, ACT, AMB, TRN, ITC and PM ASO stations, a warm area conditioned by the anthropogenic influence and by the topographic characteristic - lowland region (Fig. 7).

The principal cause of the heating inside the city is human induced, determined, first of all by the active surface. This fact is demonstrated through the profiles realised in the study area: starting from West to East, between PM PAT and PM SAL and from South to North, between PM - MOA and PM - AND (profile - Fig. $7 \mathrm{~b}$ - realised between the points and routes which could be followed in the Figure 7).

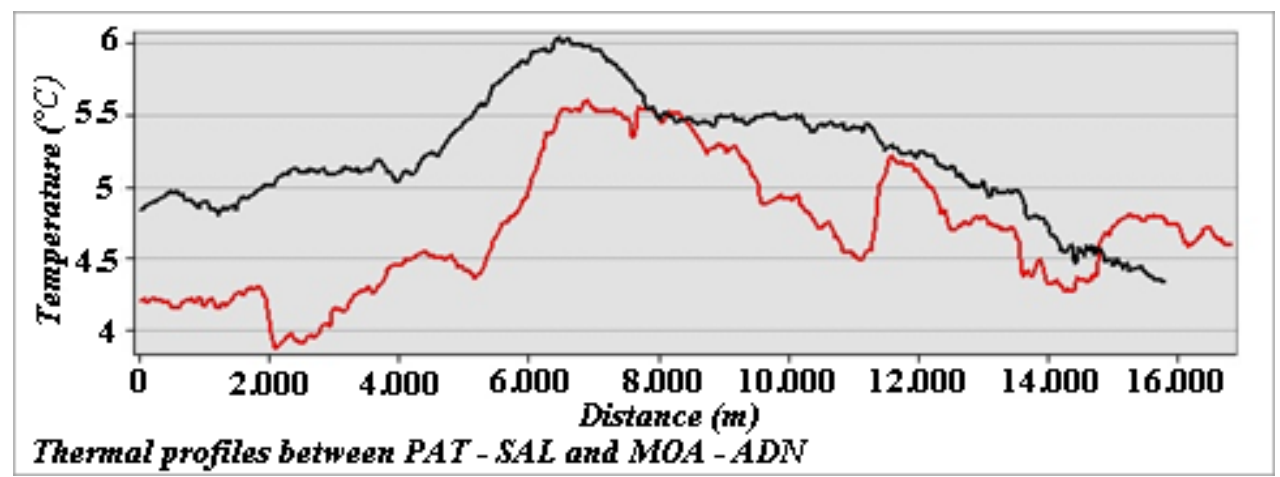

Figure 7b. Thermal profiles between PM - PAT and PM - SAL respectively between PM - MOA and PM - DNA made for temperature during winter days, for the time interval $13^{00}-16^{00}$

From the observations realised in case of air temperature repartition, during summer nights, we can observe two areas considered as two urban heat islands. Those two areas are separated by the Siret Valley, a coldest area. The urban heat islands are more prominent in the range 21PM - 5AM (Fig. 8), against the range started from 1AM till 4AM (Fig. 9). The fact is conditioned by the cooling of the active surface during night. Those two areas are hardly affected by the human impact. In the first case, on the left side of Suceava River (ACT, AMB, BUO, BUS areas), we found a heavily populated neighbourhood, with collective houses, parking areas (BUA, BUS), which store the heat during the day. We can take also in consideration also the industrial area (AMB, ACT), with specific activities which generates a high level of heat. 


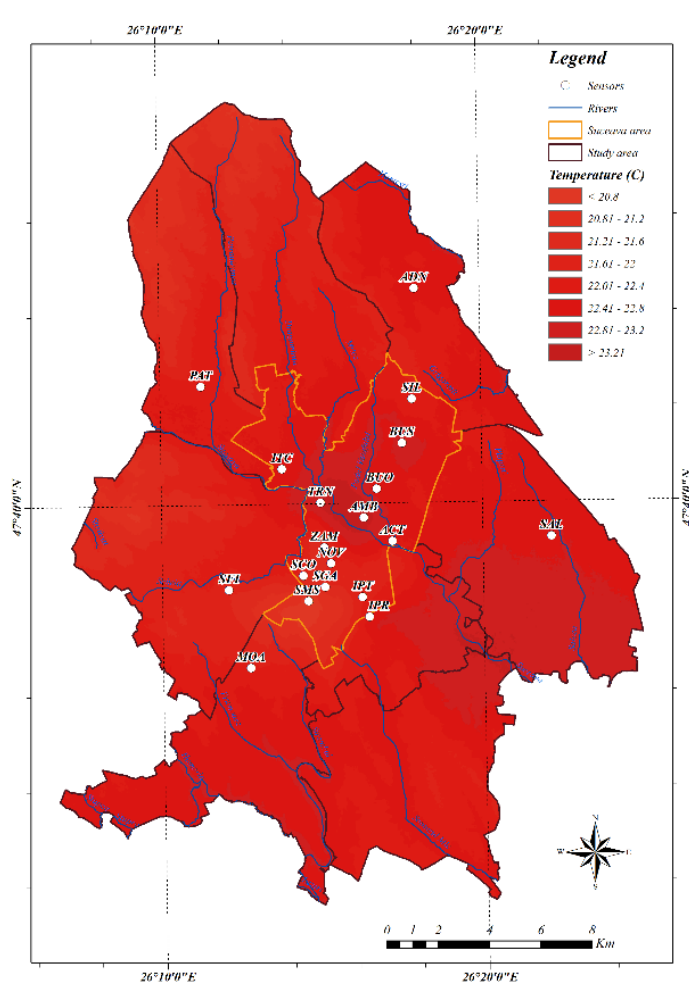

Figure 9. Repartition of air temperature during summer days for the range $06^{00}-20^{00}$

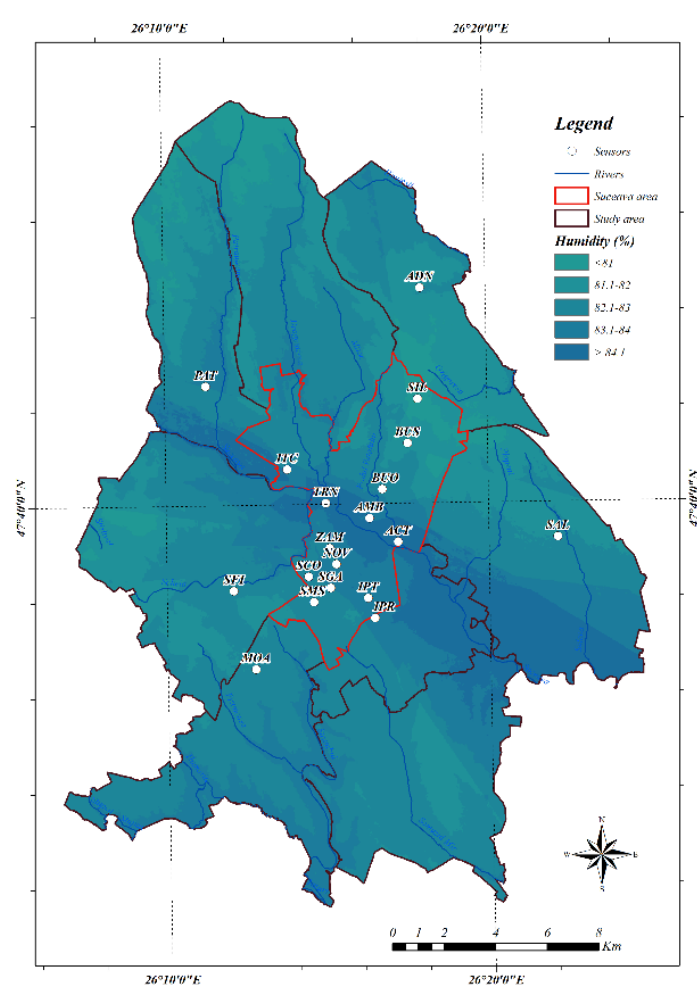

Figure 11. Repartition of air humidity during winter nights for the range $18^{00}-07^{00}$

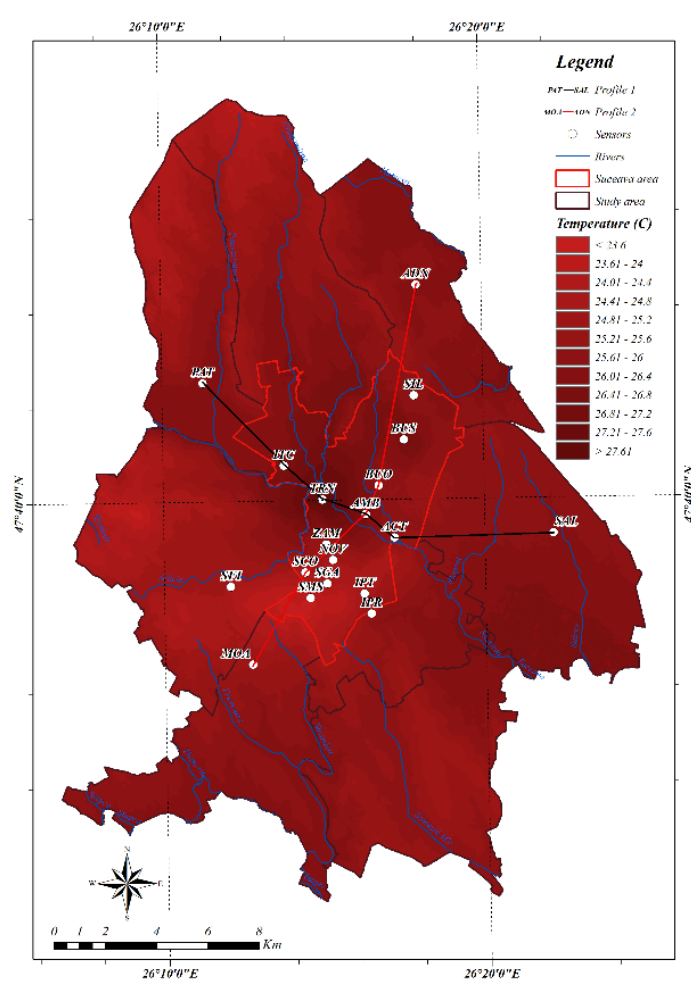

Figure 10. Repartition of air temperature during summer days for the range $13^{00}-16^{00}$

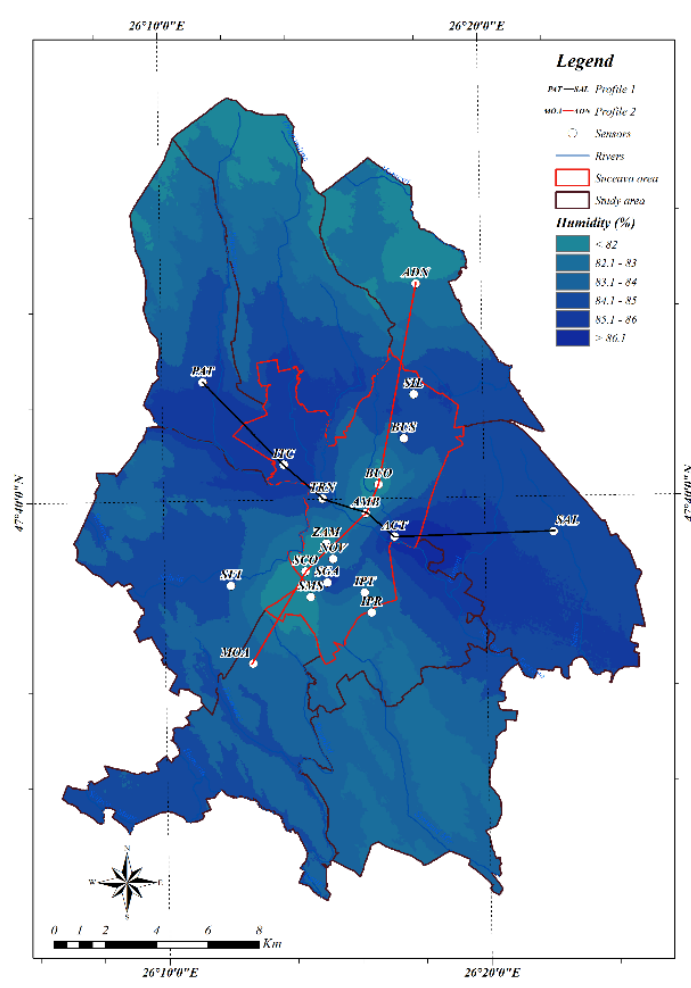

Figure 12. Repartition of air humidity during winter nights for the range $01^{00}-04^{00}$

In case of AMB is about a cardboard factory, extended to a few hectares, covered in concrete and crowded by constructions. In the case ACT, is about a wastewater plant, 
where the basins full of warm water exudes additional heat. We can complete the list of human induced influence by mentioning that in the area we found also two commercial centres of the City (Suceava Shopping City and Iulius Mall), with a huge concrete parking.

Therefore, the temperature during night is above $16^{\circ} \mathrm{C}$ in the first time frame, and above $14^{\circ} \mathrm{C}$ in the second time frame. The urban heat island from the vicinity of Suceava River, includes an intensely populated area, with collective houses, with greater height rating and obviously with a high heat storage capacity. Are also presented some surfaces covered by concrete (Metro Hypermarket).

During summer days - Fig. 9 and Fig.10, we can observe an area with highest temperatures, on both sides of the central part of Suceava River and the surroundings: PM TRN, ITC, AMB, ACT, BUO, BUS, SCO. This area is affected by the human impact, where the primary active surface of the ground was replaced by build-up-area. Many areas are covered by concrete which determine a overheating of the air.

This thing is exemplified in the range 1PM-4PM, when the values of solar radiation are at the maximum and all the surfaces of buildings are heating. Another triggering factor for the overheating is the exposure of the relief. The area corresponds with the Siret major riverbed, determining a surplus of heat at middle of the day, in all the constructed areas. Outside the city, at SMSv is the coldest region, fact which explains the positioning of the meteorological station, where the air circulation it is not conditioned by the human induced factor. The second meteorological parameter analysed is represented by the atmospheric humidity. The distribution of the atmospheric humidity in the metropolitan area of Suceava, is conditioned by the relief (altitudes, slope aspect), the characteristics of the active surface, the degree of surface cover and the anthropogenic factor.

During winter nights, the relative humidity has a mean value of $82,4 \%$ for all the study area. The lowest value was registered at PM BUO (80 \%), and the highest was 84,9\% (registered at PM ACT). We can also observe the existence of a humid region which corresponds with the corridor area of Suceava River. The main cause is represented by thermal inversions and the high frequency of the fog (Fig. 11).

During winter, in the range 1AM - 4AM (Fig. 12), the city is more dried, and an area with high humidity is located along Suceava riverbed (orientation from NV to SE). The values of the humidity are decreasing starting from Suceava River through the urban core from Burdujeni and Areni-Mărășești-Obcini. In the periphery and at the limit with AMSV, the humidity is again high because of the vegetation cover and the highest altitudes.

During winter days, the humidity is lower along Suceava River (Fig.13), process conditioned by high values of the temperature. In some regions, characterized by high altitude - all the wooded ridges around Suceava, where the snow thickness is bigger and the soil humidity reached high values, also, the value of humidity is highest.

In the middle of winter days, when the mean temperature of the city is higher, the air becomes driest (Fig. 14). The slopes from the left part of Suceava River, with a southern or south - western exposition, are the driest ones (PM PAT, BUO, BUS). The minimum value of humidity, was calculated for PM AMB $(75,9 \%)$ occurred in conditions of fast heating of the active surface, conditioned by maximum of the day and also by the anthropogenic impact through all the constructions from the region.

During winter days, the humidity is lower along Suceava River (Fig.13), process conditioned by high values of the temperature. In some regions, characterized by high 
altitude - all the wooded ridges around Suceava, where the snow thickness is bigger and the soil humidity reached high values, also, the value of humidity is highest.

In the middle of winter days, when the mean temperature of the city is higher, the air becomes driest (Fig. 14). The slopes from the left part of Suceava River, with a southern or south - western exposition, are the driest ones (PM PAT, BUO, BUS). The minimum value of humidity, was calculated for PM AMB $(75,9 \%)$ occurred in conditions of fast heating of the active surface, conditioned by maximum of the day and also by the anthropogenic impact through all the constructions from the region.

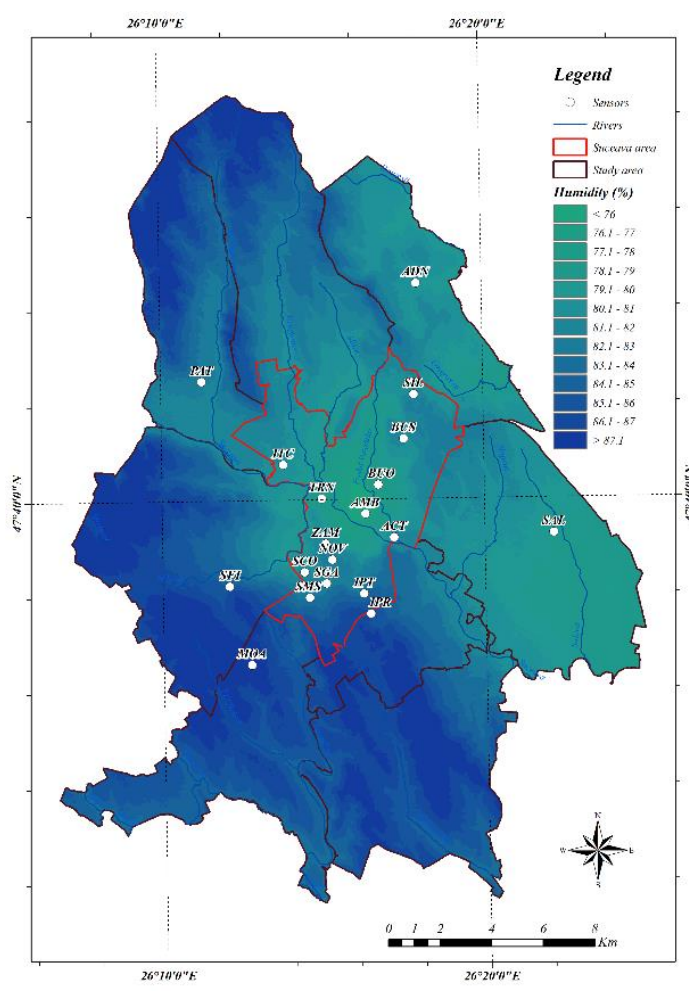

Figure 13. Repartition of air humidity during winter days for the range $08^{00}-17^{00}$

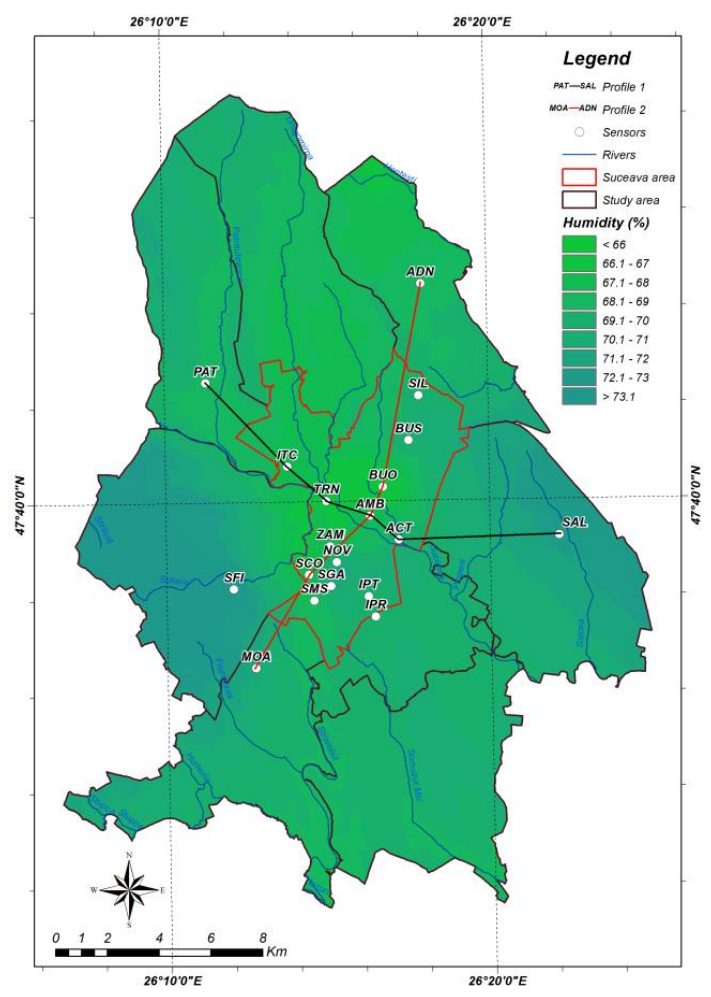

Figure 14. Repartition of air humidity during winter days for the range $13^{00}-16^{00}$

The highest values of humidity corresponds with the peripheral regions of the study area, also to the slopes with western exposition. The maximum value of the humidity reached $88 \%$ (PM MOA), in south-west of AMSV, where the human impact is insignificant.

The distribution of humidity during summer nights, shows that the city is driest (BUS, TRN, ZAM, SCO), due to higher temperature and human induced impact (Fig. 15). In exchange, it appears an excess of humidity, like an island, conditioned by local conditions of PM ACT - the water purification process which generates air humidity, and PM SGA, where the humidity is generated by Cetăţii River.

During summer in the range 1AM - 4AM, all the territories around Suceava, are characterised by highest value of humidity. The excess humidity island is more pronounced, extending to PM IPT (Fig. 16). 


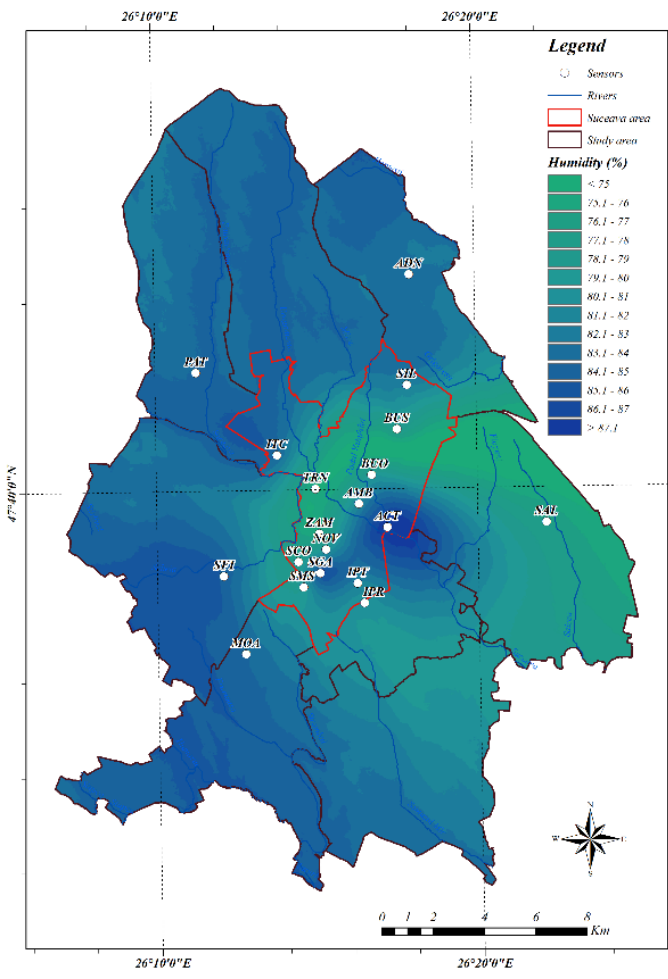

Figure 15. Repartition of air humidity during summer nights for the range $21^{00}-05^{00}$

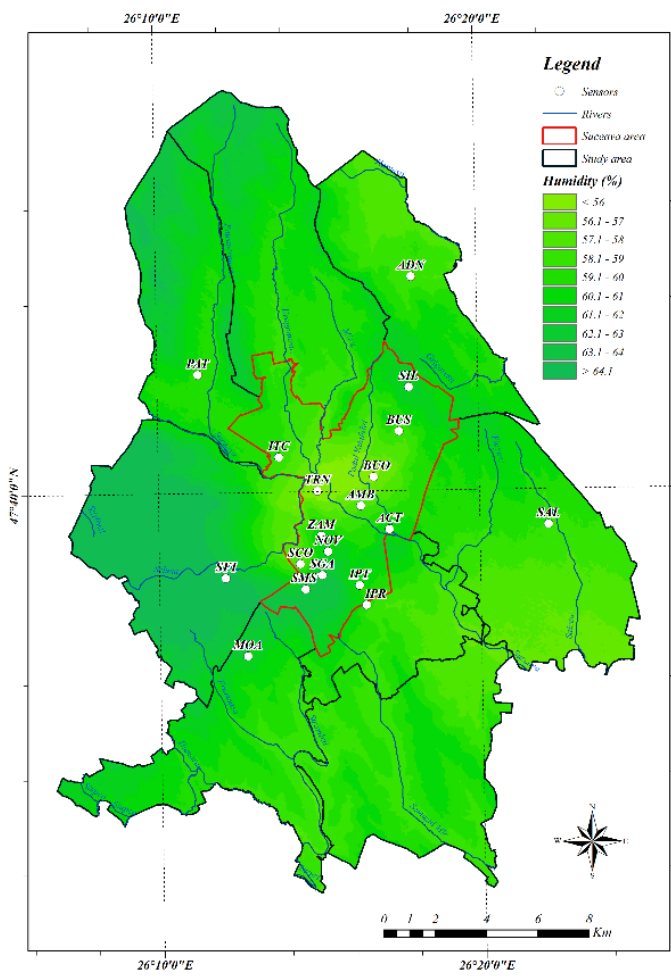

Figure 17. Repartition of air humidity during summer days for the range $06^{00}-20^{00}$

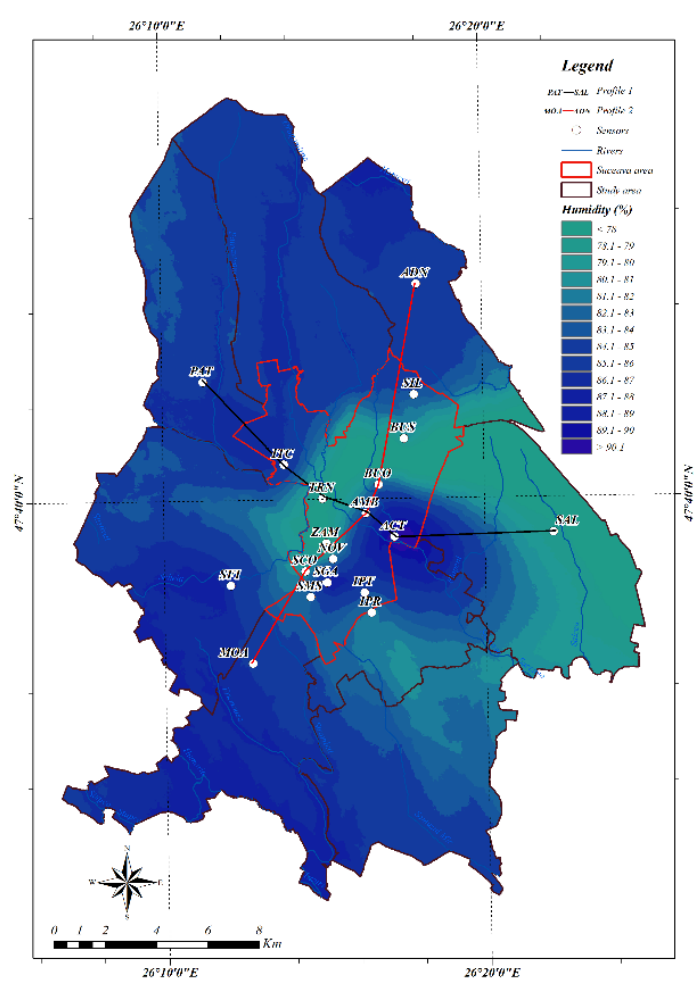

Figure 16. Repartition of air humidity during summer nights for the range $01^{00}-04^{00}$

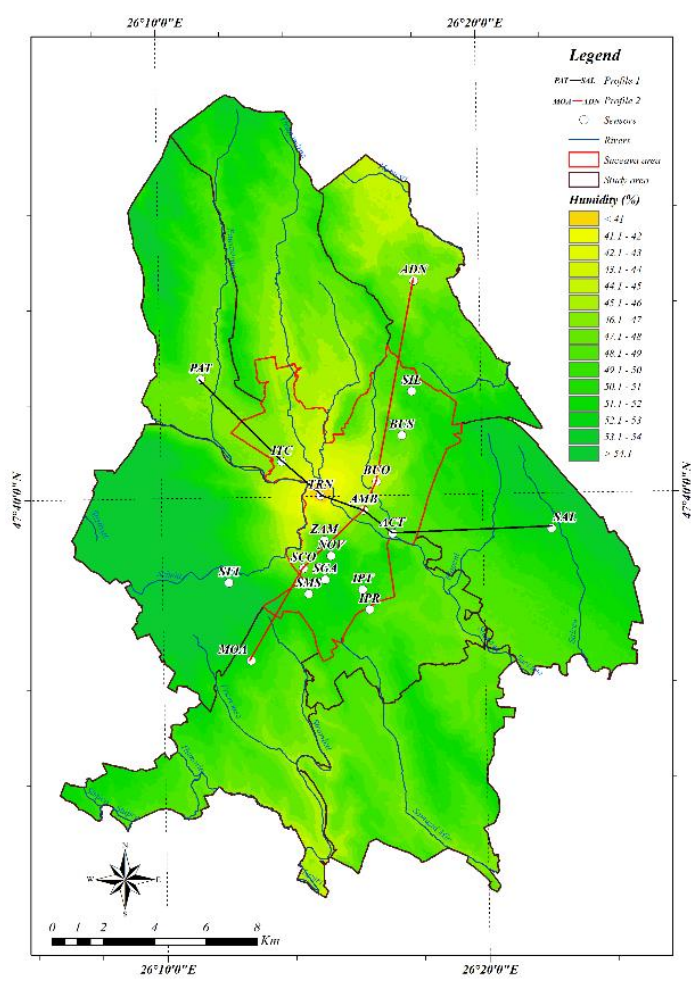

Figure 18. Repartition of air humidity during summer days for the range $13^{00}-16^{00}$ 
Summer days point out an area with lowest values of humidity, with the centre in PM TRN (Fig. 17). Moreover, at PM TRN we have registered the lowest value of humidity from all the study area: 55,5\%. During summer, in the range 13PM - 16PM, we found driest air (Fig.18), with values of humidity of $40,4 \%$ at PM TRN.

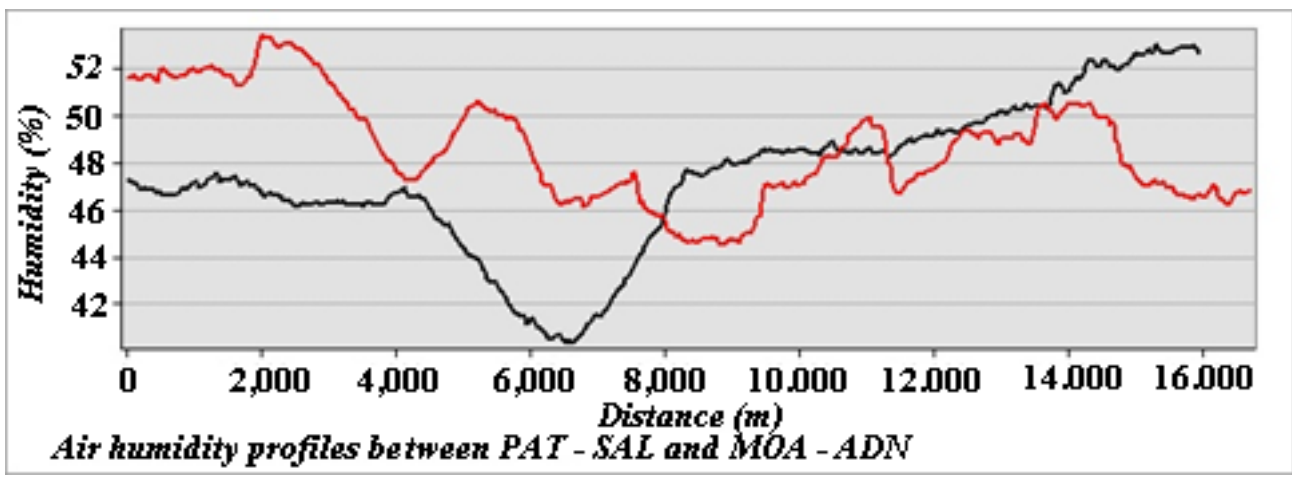

Figure 18b. Humidity profiles between PM PAT and SAL / PM MOA and PM ADN - relative humidity during summer days for the range $13^{00}-16^{00}$

The highest values of relative humidity are founded out of the territories densely populated, with the highest values in the central - western part, at PM SFI (64,6\%), to a slope with a wide opening toward the west, favouring the intrusion of humid air.

The influence of the city on relative humidity values distribution, is highlighted also by air humidity profiles between PM PAT - SAL and PM MOA - AND observation points (the profile from Fig. 18b, realised between the points and routes which can be seen in Fig. 18). The differences between air humidity from the urban area and the suburban area can reached values of $8-14 \%$ during midday in summer.

\section{CONCLUSIONS}

Even if Suceava City has a multi-core structure, overlapped with a specific typology of landforms (hills, lowland areas and plateaus with steep slopes, with various structure and aspect), in case of air temperature repartition, we can observe two areas, one with highest values and another with the lowest ones.

In the first case we took in consideration a densely populated territory and with productive use (industrial platforms and economic retail units), which, through the construction materials type, determined a pronounced heating. In the second case we analysed surfaces with a low degree of human influence.

During summer nights (in the range 18PM - 7AM), the thermic differences between the warmest artificial territories of the city and the unmodified ones, can reached at $1,8^{\circ} \mathrm{C}$, during summer nights $(9 \mathrm{PM}-5 \mathrm{AM})$, it can be $2,5^{\circ} \mathrm{C}$. During winter days $(8 \mathrm{AM}-5 \mathrm{PM})$, the thermic differences between the same areas can reached to $2,0^{\circ} \mathrm{C}$. During summer, between 6AM and 8PM, those differences are at $3,1^{\circ} \mathrm{C}$.

Some areas from Burdujeni neighbourhood and city centre, some industrial areas and commercial premises, areas from ACET - AMBRO, territories with a favourable slope aspect and with a good position for air circulation during winter, were warmest than some anthropogenic regions from the city area and the surroundings. Also we can compare it with some half-shaded territories, characterised by moisture, and favourisinf thermic inversions, during winter with $1,9^{\circ} \mathrm{C}$, ad during summer, with $2,8^{\circ} \mathrm{C}$ (the mean for the region is $2,3^{\circ} \mathrm{C}$ ). 
The surface active and relief characteristics are conditioned by the relative humidity values repartition. The hyghric differences between the urban territories most modified and the urban and suburban less modified or non-modified, reached values of 8-14\% during midday summer, till 3 - $4 \%$ during winter nights. In conclusion, the atmospheric air above the city is warmest and driest compared to the surroundings.

\section{REFERENCES}

[1] - Dumitrescu E. - Climate of Bucharest, "Ars Docendi" Publishing House, Bucharest (in Romanian: Clima oraşului Bucureşti, Editura „Ars Docendi”, Bucureşti) (2008);

[2] - Alexe C - Climate and topoclimate of Iasi and metropolitan area. PhD thesis, "Alexandru Ioan Cuza" University, Iasi (in Romanian: Clima şi topoclima municipiului Iaşi şi a ariei metropolitane. Teză de doctorat, Universitatea „Alexandru Ioan Cuza”, Iaşi) (2012);

[3] - Cheval S., Dumitrescu A. - The summer surface urban heat island of Bucharest (Romania) retrieved from MODIS images (2015)

[4] - Ichim P. et. al. - Characteristics of nocturnal urban heat island of Iaşi during a summer heat wave (1-6 of august 2017), Aerul si Apa. Componente ale Mediului, Cluj Napoca (2018)

[5] - Lokoshchenko M.A. - Urban heat island in Moscow, Urban climate, vol. 10, part. 3, pp. 550 $-562(2014)$

[6] - Yang L. et. al. - Research of Urban Heat - Island Effect, Procedia Engineering, Science Direct (2016), vol.169. pg.11 - 18

[7] - Kohler M. et. al. - Impacts of several urban-sprawl countermeasures on building (space heating) energy demands and urban heat island intensities. A case study, Urban climate, vol. 19, pp. $92-121(2017)$

[8] - Li H. et. al. - A new method to quantify surface urban heat island intensity, Science Direct (2018), vol. 624, pg. $262-272$;

[9] - Imbroane A.M. - Geographic Information Systems, vol. II - Spatial analysis and modeling, Cluj University Press Publishing House (in Romanian: Sisteme Informatice Geografice, vol. II Analiză spaţială şi modelare, Editura Presa Universitară Clujeană), (2018). 